reduziertem reinen Cytochrom $b_{5}$ (hergestellt nach ${ }^{6}$ ) wird durch Ascorbinsäure nicht beeinflusst.

Dehydroascorbinsäure (hergestellt nach, frei von Ascorbinsäure), wirkt im DPNH-Oxydasetest und bei der Cytochrom $b_{5}$-Reoxydation genauso wie Ascorbinsäure. Dies steht im Widerspruch zu Ergebnissen, nach denen Dehydroascorbinsäure unwirksam war ${ }^{1}$.

Die vorliegenden Befunde erlauben den Schluss, dass Ascorbinsäure in der DPNH-abhängigen mikrosomalen Atemkette als Elektronenüberträger zwischen Cytochrom $b_{5}$ und Sauerstoff wirksam ist.

Physiologisch-chemisches Institut, Friedrich-Schiller-Universität, Jena (Deutschland)

HORST FRUNDER Eva Blume

HARALD KLUGE

1 H. Kersten, W. Kersten und H. Staudinger, Biochim. Biophys. Acta, 24 (I957) $222 ; 27$ (1958) 598 .

2 K. Krisch und H. Staudinger, Biochem. Z., 33 I (I959) 195.

3 D. Garfinkel, Arch. Biochem. Biophys., 77 (I958) 493.

4 E. Blume, H. Kluge und H. Frunder, Acta Biol. Med. Germ., im Druck.

5 H. Kluge, E. Blume und H. Frunder, unveröff. Versuche.

- P. Strittmatter und S. F. Velick, J. Biol. Chem., 22 I (I956) 253.

7 R. Pohloudek-Fabini und W. Fürtig, Arch. Pharmacol., 292 (I959) 350.

Eingegangen am 3 Juli, I 962

Biochim. Biophys. Acta, 65 (1962) I46-148

\title{
Free-boundary electrophoresis of histones
}

SC 2140

While as a rule electrophoresis is carried out at $\mathrm{pH}$ values above the iso-electric point of proteins, the very high iso-electric point of histones (about $\mathrm{pH}$ I2) perforce leads to electrophoresis below this value. As a matter of fact, the published free-boundaryelectrophoresis diagrams of histones (see e.g. refs. I, 2) are all marred by an exceptionally strong discongruence of the ascending and descending boundaries.

In our experiments on the lysine-rich fraction of calf-thymus histone we have also always found this lack of enantiography (see Fig. I), as long as electrophoresis
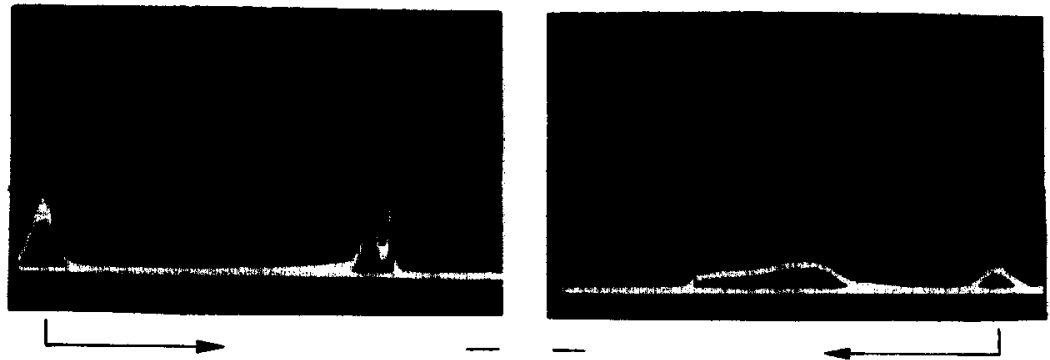

Fig. I. Electrophoresis of lysine-rich fraction of calf-thymus histone in sodium diethylbarbituratesodium acetate- $\mathrm{HCl}$ buffer, $\mathrm{pH} 8.2, I$ o. Io; 5000 sec. 


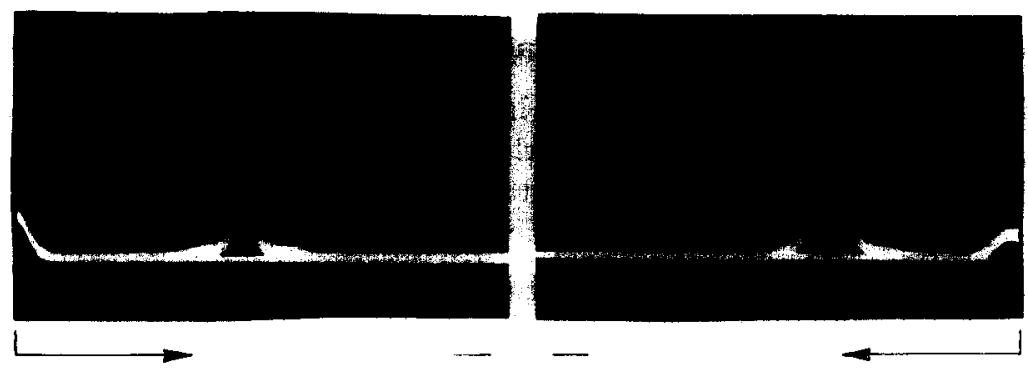

Fig. 2. Electrophoresis of same preparation as used in Fig. 1 in Tris-HCl buffer, pH 8.2, $I$ o.10; $6000 \mathrm{sec}$.
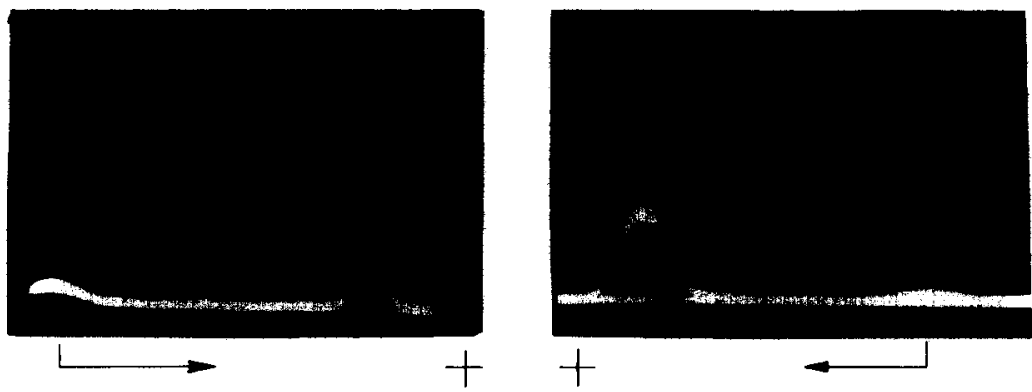

Fig. 3. Electrophoresis of bovine serum albumin in Tris- $\mathrm{HCl}$ buffer, $\mathrm{pH} 8.2, I 0.10 ; 15000$ sec.

was carried out in the customary buffers, diethylbarbiturate-acetate or acetateacetic acid (sodium salts).

Now above its iso-electric point a protein will migrate in the same direction as the buffer anions, below this point in the same direction as the buffer cations. This explains the seemingly abnormal behaviour of histones in free-boundary electrophoresis, as the best enantiography is obtained in a medium with slowly-moving buffer ions bearing the same sign as the proteins ${ }^{3}$.

Indeed a much better enantiography was achieved by performing the electrophoresis of the histone in Tris- $\mathrm{HCl}$ buffer of $\mathrm{pH} 8.2$ (Fig. 2), in which the slowlymoving Tris cation migrates in the same direction as the histones, while in this same buffer bovine serum albumin (iso-electric point about 4.6) showed a very pronounced lack of enantiography (Fig. 3).

We trust that the publication of this observation will prove useful to other workers in the field of histones.

Laboratory for Physiological Chemistry, The University,

E. H. DE NoOIJ Utrecht (The Netherlands)

J. A. NIEMEIJER

1 P. F. Davison, D. W. F. James, K. V. Shooter and J. A. V. Butler, Biochim. Biophys. Acta, I5 (I954) 4I 5 .

2 N. Ui, Biochim. Biophys. Acta, 25 (1957) 493.

${ }^{3}$ L. G. Longsworth, in M. Bier, Electrophoresis, Academic Press, Inc., New York, I959, p. I13.

Received July 4th, I962 